\title{
Hans Küng en religieuse pluraliteit
}

\author{
Dirk J Louw ${ }^{*}$ \\ Navorsingsgenoot: Departement Filosofie \\ Universiteit van die Vrystaat
}

\begin{abstract}
Hans Küng and religious plurality

The article traces Hans Küng's view on religious plurality over four decades: from "theocentrism" (the earlier Küng) to critical ecumenical dialogue (the later Küng). Küng's approach to religious plurality portrays a growing openness towards non-Christian religions. However, his approach is not quite as accommodative as it may appear on face value. On closer inspection, the "theocentrism" of the earlier Küng turns out to be (merely) christocentrism, and the "maximal" openness that supposedly informs the later Küng's critical ecumenical dialogue (and concomitant ecumenical criteria) turns out to be a "committed" openness. Although Küng's approach seemingly constitutes a shifting of the Christian criterion, it is therefore best understood as merely a movement in the Christian criterion. This prompts the question as to whether an unbiased assessment of religions is possible at all.
\end{abstract}

\section{INLEIDING}

Christene bevind hulle te midde van 'n pluraliteit van religieuse tradisies wat elk ' $n$ aanspraak op "waarheid" maak. Wat behoort die Christen se houding te wees ten opsigte van die waarheid van nie-Christelike godsienste? Hoe behoort Christene te oordeel oor die religieuse ander? Antwoorde wat op hierdie vraag gegee word, lei dikwels tot konflik, selfs bloedvergieting. Soos Tom Driver tereg opmerk: "over the whole discussion of [religious] pluralism there hangs the specter of colonialism, neo-colonialism, imperialism, exploitation of the weak, and warfare. It is this history that makes the topic urgent." (Driver 1987:217)

Die bekende Rooms-Katolieke teoloog, Hans Küng, hou homself al meer as vier dekades intensief besig met kwessies rondom religieuse

\footnotetext{
* Die finansiële ondersteuning van die (destydse) Sentrum vir Wetenskaplike Ontwikkeling (SWO) vir hierdie navorsing word hiermee erken. Menings wat in hierdie artikel uitgespreek is en konklusies wat getrek is, is die van die outeur en weerspieël nie noodwendig die standpunt van die SWO nie.
} 


\section{Hans Küng en religieuse pluraliteit}

pluraliteit en die houding van Christene teenoor ander godsdienste. Wat volg, is 'n poging om Küng se denke in hierdie verband krities na te speur. Ek hoop om aan te toon dat, hoewel sy standpunt skynbaar deur 'n groter wordende openheid jeens nie-Christelike godsdienste gekenmerk word, hierdie openheid steeds op 'n gespanne voet staan met sy fundamentele verbintenis tot die Christelike godsdiens. Hierdie spanning manifesteer by uitstek in sy begrip van 'n kritiese ekumeniese strategie en van die ekumeniese kriteria wat dit ten grondslag lê.

\section{DIE VROEËRE KÜNG: "TEOSENTRISME”}

\subsection{Küng en Rahner}

Küng ontwikkel 'n eerste standpunt ten opsigte van die sogenaamde "probleem van religieuse pluraliteit" in reaksie op Karl Rahner se nou reeds bekende konsep van "anonieme Christenskap". Volgens laasgenoemde is 'n lid van 'n "ekstra-Christelike" godsdiens niks minder as 'n "anonieme Christen" nie (Rahner 1981:75). Sy is 'n "Christen" in soverre God se reddende genade aan alle mense (en daarom ook aan haar) geopenbaar is en in soverre alle redding/verlossing in en deur Christus geskied (Rahner 1981:76; 1978:311). Sy is 'n "anonieme" Christen in soverre sy hierdie "goddelike gawe van genade ongereflekteerd en implisiet aanvaar" (Rahner 1981:77), dit is in soverre sy hierdie gawe nie eksplisiet as 'n gawe van God in en deur Christus dui nie. Rahner se standpunt verwoord in 'n mindere of meerdere mate steeds die benadering van die meerderheid van Rooms-Katolieke teoloë. Die invloed van Rahner kan ook bespeur word in die Rooms-Katolieke ekklesiologie sedert Vatikaan II (Knitter 1985:130) en die (skynbare) afswakking van die bekende extra ecclesiam nulla salus (dit is "buite die kerk geen verlossing nie").

Nie alle Rooms-Katolieke teoloë is egter beïndruk met Rahner se idee van "anonieme" Christenskap nie. Met name Hans Küng beskou hierdie idee as bloot die nuutste, deursigtige teologiese "fabrikasie" om die Rooms-Katolieke standpunt dat geen verlossing buite die Rooms-Katolieke Kerk moontlik is nie, van niksseggendheid te red:

... is not the whole of good-willed humanity thus swept with an elegant gesture across the paper-thin bridge of a theological fabrication into the back door of the "holy Roman Church", leaving no one of good will "outside"? The formula, "no salvation outside the Church", is then as true as ever, because all in fact are in the Church from the very beginning: not as formal, but as "anonymous" Christians or - as we ought logically to say - "anonymous Roman Catholics".

(Küng 1976:98) 
As sodanig klop die idee van anonieme Christenskap nie met Küng se ervaring van nie-Christelike godsdienste nie. Küng weet byvoorbeeld van geen opregte, self-respekterende Boeddhis, Jood of Moslem wat na volle lidmaatskap van die kerk "hunker" nie, of wat die veronderstelling dat hy/sy 'n anonieme Christen is, nie as uiters verwaand sou beskou nie. Hoe sou Christene immers reageer op die bewering dat hulle, byvoorbeeld, anonieme Boeddhiste is, selfs al word dit met die beste bedoelings ter wêreld beweer? Hierbenewens ondermyn die idee van anonieme Christenskap volgens Küng die eiesoortigheid of uniekheid van Christus en die Kerk. 'n Kerk wat orals is, is immers nêrens. Só word dit juis niksseggend om te beweer dat geen verlossing buite die Kerk moontlik is nie:

\begin{abstract}
Are we not thus in danger ... of diminishing the reality of Christianity merely to save an infallible formula?... are we not making the Church equivalent to the world, Christendom to humanity? Does not Christianity thus become a religious luxury and the Christian ethos superfluous?...does not Jesus in the last resort become all too easily an avatar for the Hindus, a bodhisattva for the Buddhists, one of the prophets for the Muslims?
\end{abstract}

(Küng 1976:98)

\title{
1.2 Küng versus Rahner?
}

Alhoewel Küng hom eers in Christ sein (1974) behoorlik teen Rahner se idee van anonieme Christenskap uitspreek, kan kritiek op hierdie idee reeds in eersgenoemde se Freedom today (1966) ${ }^{1}$ aangetref word (Küng 1969:203, 215). In dieselfde werk ontwikkel Küng egter 'n standpunt ten opsigte van die "legitimiteit" van nie-Christelike godsdienste wat op die oog af nie beduidend van dié van Rahner, en spesifiek van sy begrip van anonieme Christenskap, verskil nie. Die standpunt van $\mathrm{Küng}^{2}$ kan in die volgende tien punte saamgevat word: (i) dat dit God se wil is dat alle mense gered moet word en dat Hy daarom toesien dat ook diegene wat om een of ander rede nie met die evangelie gekonfronteer is of word nie, gered word of sou kon word (Küng 1969:202, 204-206, 211-212); (ii) dat God sy genade aan die ganse mensdom via die skepping (waarvan die mens 'n deel is) gekommunikeer het en dat Hy op hierdie manier inherent deel van en noodsaaklik vir die bestaan van elke mens is (Küng 1969:205206); (iii) dat die mens en dus ook die gelowige essensieel 'n sosio-histories

\footnotetext{
1 'n Bundel essays deur Küng. Ek konsentreer hier spesifiek op een van hierdie essays, te wete The freedom of religions, soos opgeneem in Thomas (1969:193-217). Vergelyk ook Küng (1966:110-124; 132-145; 147-148; 159-160).

${ }^{2}$ Soos gesê, gaan dit hier om 'n eerste standpunt van Küng of die "vroeëre" Küng.
} 


\section{Hans Küng en religieuse pluraliteit}

gesitueerde wese is en dat hy nie sonder meer kan ontsnap uit sy “... particular individual and social environment ..." en die "... religion socially imposed on him ..." (Küng 1969:211) nie; (iv) dat die redding of verlossing van 'n nie-Christen daarom noodwendig moet geskied via sy spesifieke godsdiens, en dat nieChristelike godsdienste dus as "ways of salvation" beskou sou kon word (Küng 1969:212); (v) dat die reddende kapasiteit van nie-Christelike godsdienste egter nie beteken dat hierdie godsdienste sonder foute of "sonde" is nie (Küng 1969:210), of, anders gestel, hierdie godsdienste bevat slegs elemente van waarheid en is daarom slegs gedeeltelik "legitiem" (Küng 1969:212); (vi) dat nieChristene nie hierdie elemente van waarheid eksplisiet as dié Waarheid (dit is as "the Gospel of Christ") herken nie (Küng 1969:213, 214); (vii) dat verlossing in en deur Christus, “... and in him alone ...", aan ons geskenk word "... whether a person of goodwill ultimately finds himself inside or outside the visible communion of those who believe in and confess Christ" (Küng 1969:204); (viii) dat die legitimiteit of reddende kapasiteit van nie-Christelike godsdienste verval wanneer hierdie godsdienste met die evangelie gekonfronteer word (Küng 1969:210-211, 212); (ix) dat die kerk nie meer uitsluitlik die weg van verlossing of redding konstitueer nie, maar (bloot) die sigbare teken is van "... the fulfillment of all things which is the work of God ..." (Küng 1969:217; vgl ook 1969:203), en van 'n "... invitation to the peoples so that from Christians de jure they may become Christians de facto; from Christians in spe, Christians in re ..." (Küng 1969:217); en (x) dat die kerk of die Christelike godsdiens nietemin steeds as die normatiewe en superieure weg van verlossing of redding beskou moet word, oftewel, die kerk konstitueer steeds “... the high and excellent and 'extraordinary' way of salvation" (Küng 1969:213), terwyl die nie-Christelike godsdienste die “'ordinary' way of salvation for non-Christian humanity" (Küng 1969:211) is.

In die lig van hierdie stellings behoort dit nou reeds duidelik te wees dat Küng se eie standpunt met moeite van dié van Rahner onderskei kan word. Küng bestempel sy eie benadering as 'n "teosentriese" (teenoor "ekklesiosentriese") benadering. 'n Ekklesiosentris neem die kerk as uitgangspunt in sy besinnings oor nie-Christelike godsdienste. 'n Teosentris, daarenteen, benader die nie-Christelike godsdienste in die lig van God se "free and all-embracing grace" (Küng 1969:204). Of, soos Küng dit stel, ekklesiosentriste “... proceed ... form intra to extra ..." en teosentriste “... form extra to intra. ..." (1969:205):

The question of what lies outside the Church is one which can be asked but ... is difficult to answer. As to what lies outside God and his plan of salvation, this is not a real question at all. If we look at God's plan of salvation, then there is no extra, only an intra; no outside, only 
an inside, for "God desires all men to be saved and to come to the knowledge of the truth. For there is one God, and there is one mediator between God and men, the man Christ Jesus, who gave himself as a ransom for all" (1 Tim 2.4-6).

(Küng 1969:206)

Hierdie opmerkings is beslis gemik teen die tradisioneel Rooms-Katolieke standpunt "buite die kerk geen verlossing nie" (Küng 1969:204). Dit is skynbaar ook teen Rahner gemik. Maar nou bly die vraag: presies hoe en waar verskil Küng se eie standpunt van dié van Rahner? Op die oog af wil dit immers voorkom asof die enigste verskil tussen die standpunte van Rahner en Küng die feit is dat laasgenoemde nie die term "anonieme Christen" gebruik nie.

In die lig van Küng se kritiek op Rahner se idee van anonieme Christenskap, sou die antwoord op hierdie vraag moontlik kon wees dat dit allermins Küng se bedoeling is om, soos Rahner, die begrip kerk as 't ware só te "rek" dat dit uiteindelik alles sou kon insluit wat vir hom mooi, goed en reg lyk (Fil 4:8; Küng 1969:211). Vir Rahner konstitueer die kerk die waarheid, dit wil sê die kerk is orals waar die waarheid aangetref word, ook al sou dit in nie-Christelike godsdienste wees. Hierteenoor wil Küng sê (of, sou hy graag wou sê) dat nieChristelike godsdienste in eie reg, dit is onafhanklik van die Kerk of die Christelike godsdiens, "ways of salvation" is. Vandaar sy fel kritiek op die arrogansie van die idee van anonieme Christenskap en die "... totalitarian domination of one religion ..." (Küng 1969:216). Vandaar ook sy klem op die "vryheid" van godsdienste (Küng 1969:216), op Christelike self-kritiek (Küng 1976:114) en op interreligieuse dialoog, dit is op die feit dat Christene ook iets van nie-Christene sou kon leer (Küng 1976:112). By dit alles voeg Küng egter in één asem dat Christus steeds die uiteindelike en absolute norm vir waarheid is (Küng 1969:214, 216; 1976:123). Trouens, volgens Küng dien die Christelike godsdiens as 'n noodsaaklike "kritiese katalisator" vir nie-Christelike godsdienste. Hiervolgens kan die nie-Christelike godsdienste nie werklik sonder die Christelike godsdiens hul soteriologiese kapasiteit verstaan en realiseer nie, veral nie in ons moderne, tegnologiese wêreld nie. Die nie-Christelike godsdienste het die Christelike godsdiens nodig om hul van hul "unhistoricity, circular thinking, fatalism, unworldliness, pessimism, passivity, caste spirit" en "social disinterestedness" te verlos en om só "... what is best and deepest in them" na vore te bring (Küng 1976:110, 112; vgl ook 1976:106-112).

Uiteindelik huldig Küng dus twee moeilik versoenbare standpunte. Die eerste lui dat nie-Christelike godsdienste in eie reg waar is, dat Christene van hierdie godsdienste kan leer en dat Christene bereid moet wees om hul eie 


\section{Hans Küng en religieuse pluraliteit}

standpunt te hersien "... wherever this turns out to be in need of revision" (Küng 1976:114). Die tweede lui dat die waarheid van nie-Christelike godsdienste nie onafhanklik van die Christelike godsdiens geïdentifiseer en gerealiseer kan word nie, dit is dat die Christelike godsdiens steeds "absoluut" waar is, dat Jesus Christus steeds die uiteindelike en absolute norm vir waarheid bly. Küng skryf:

... It is the Gospel of Jesus Christ that is able to liberate the truth of the world religions from their entanglement in error and sin. Though the religions do in many ways proclaim the truth of Christ, yet they do not know him whose truth they proclaim; in all their proclamation of truth they fail to recognize him who, as the Father's Word, is the Truth. It is this which, despite the light which they shed at very many different points, constitutes their basic darkness, in which they themselves cannot see, and which can be illuminated only by him who is the Light.

(Küng 1969:214)

Paul Knitter het dus myns insiens gelyk wanneer hy beweer dat Küng se "teosentrisme" uiteindelik op niks meer as 'n "christosentrisme" neerkom nie. As sodanig, dit is as 'n Christosentris, beskou Küng steeds vir Christus as die “... norma normans non normata ('the norm above all other norms')" (Knitter 1985:134, vgl ook 1985:142):

Others, ${ }^{3}$ who question the anonymous Christian approach but still endorse Christ as the norm for all religious experience, will admit that the religions have a validity of their own and need not be converted to Christianity. Still, even though they may not wish to admit it, these theologians must maintain that without conversion to Christ and the church, the religions remain incomplete. Adherents of other faiths are not called anonymous Christians; to be honest, however, they are considered potential Christians. Of course, that potential need not be realized for salvation to be experienced; until it is, though, something is missing.

(Knitter 1985:135)

Só verstaan, sou die verskil tussen die standpunte van Rahner en Küng miskien kortom aangedui kon word as die verskil tussen ekklesiosentrisme (Rahner) en

\footnotetext{
${ }^{3}$ Hierdie "others" verwys onder andere na Heinz R Schlette, Monika Hellwig, Walbert Bühlmann, Arnulf Camps en Piet Schoonenberg (Knitter 1986:102).
} 
christosentrisme (Küng). ${ }^{4}$ Knitter praat in hierdie verband ook van 'n "Christ within the religions"-benadering (Rahner) teenoor 'n "Christ above the religions"benadering (Küng). Teenoor eersgenoemde benadering, beskou laasgenoemde benadering nie meer vir Christus as die "konstitutiewe oorsaak" van genade nie, resp. "... Christ ... no longer needs to be within the religions to validate them ..." (Knitter 1986:102). Tog word Christus steeds as die absolute norm vir die waarheid of geldigheid van die nie-Christelike godsdienste beskou, resp. “... he still stands above them as the norm by which their validity is judged and in which they find their fulfillment" (Knitter 1986:102).

Hoe ons egter ook al die benaderings van Rahner en Küng onderskei, daar is een belangrike eienskap wat hierdie benaderings in gemeen het. Sowel Rahner as (die vroeëre) Küng verabsoluteer naamlik dogmaties en willekeurig hul eie religieuse tradisie tot die norm vir ander religieuse tradisies. In die proses diskwalifiseer hulle van huis uit die aansprake op finale en universele normatiwiteit van ander religieuse tradisies. Só verstaan, lewer hulle die normatiwiteit en waarheid van godsdienste resloos uit aan subjektiewe willekeur. Wat verhoed die lede van ander religieuse tradisies immers om op soortgelyke wyse húlle tradisies dogmaties en willekeurig tot die norm vir ander religieuse tradisies te verhef?

\section{DIE LATERE KÜNG: KRITIESE EKUMENIESE DIALOOG}

\subsection{Wêreldvrede en ekumeniese gemeenskap}

Tot voor die verskyning van sy Existiert Gott? (1978) was Küng van mening dat die ander godsdienste hulle vervulling in die Christelike godsdiens vind en dat die Christelike godsdiens as die norm behoort te dien aan die hand waarvan elemente van waarheid in ander godsdienste geïdentifiseer moet word. ${ }^{5}$ Trouens, die kontoere van wat ek as die standpunt van die "latere" Küng bestempel, kan eers na behore in sy Christentum und Weltreligionen (1985) en latere publikasies gevind word. ${ }^{6}$ In my bespreking van hierdie standpunt sal ek daarom hoofsaaklik na hierdie publikasies verwys.

Die probleem van verskillende godsdienste se botsende aansprake op waarheid val vir Küng om alle praktiese redes saam met die probleem van wêreldvrede, aangesien daar volgens hom "geen wereldvrede zonder godsdienstvrede" (Küng 1990a:22; vgl ook 1994a:132-134; 1995:18-19; 1996:782783) sou kon wees nie, en aangesien "godsdienstvrede" met name deur die

\footnotetext{
${ }^{4}$ Knitter (1985:142).

${ }^{5}$ By gesê, streng gesproke kan uiters tentatiewe voorlopers van die standpunt van die "latere" Küng reeds in sy Christ sein (1974) gevind word (vgl bv Küng 1976:114).

${ }^{6}$ Vergelyk op hierdie punt Cowdell (1989:89) en Hick (1990:176).
} 
probleem van verskillende godsdienste se botsende aansprake op waarheid verhoed word. Hy skryf:

Maar laten we wel zijn: Geen vrede onder de godsdiensten zonder een opheldering van de waarheidsvraag. Dat lijkt alleen al daarom onvermijdelijk, omdat geen enkel ander probleem in de geschiedenis van kerken en godsdiensten zoveel bloed en tranen heeft doen vloeien als deze vraag naar de waarheid.

(Küng 1990a:28)

asook:

De constructieve dialoog met de andere religies van deze wereld [met het oog op interreligieuze verzoening en een groeiende oecumenische gemeenschap] omwille van de vrede in de wereld is noodzakelijk om te overleven.

(Küng 1990a:27 - my beklemtoning; vgl ook 1990a:52; 1986c:440-443)

Só verstaan, daag die ervaring van religieuse pluraliteit ${ }^{7}$ ons uit om 'n strategie ter oplossing van die probleem van verskillende godsdienste se botsende aansprake op waarheid te vind wat as sodanig 'n bydrae sou kon lewer "... tot vrede tussen de godsdiensten en volken" (Küng 1990a:33; vgl ook 1990a:29, 48). Die vraag hier ter sake is: "[W]ith what basic attitude should the adherents of the religions deal with the question of truth, in a way that would be significant for world peace?" (Küng 1991a:81). Geeneen van vier fundamentele benaderings wat tot bovermelde probleem gevolg sou kon word, bied volgens Küng só 'n strategie of "basic attitude" nie. Onder hierdie benaderings tel vir hom die ateïstiese, eksklusivistiese, essensialistiese en inklusivistiese benaderings. Die ateïstiese benadering gaan uit van die standpunt dat geen godsdiens waar is nie, oftewel dat alle godsdienste ewe onwaar is. Benewens die algemene formulering wat hy van elk van die ander benaderings bied, formuleer Küng spesifiek ook elkeen van hierdie benaderings as 'n strategie ter verkryging van "godsdiensvrede". Hy verwys byvoorbeeld na die eksklusivistiese benadering as die "vestingsstrategie" (Küng 1990a:29) of "fortress strategy"

\footnotetext{
${ }^{7}$ Küng omskryf hierdie ervaring ook as die ervaring van “... a new post-colonial, postimperialistic, postmodern [and thus a polycentric] world constellation ... which is being bound ever closer together by new communication technologies" (1991a:135). Vergelyk ook Küng (1988b:1-11, 179, 197; 1989b:450; 1990b:61; 1991a:1-24).
} 
(Küng 1991a:78) en formuleer dit as die standpunt dat slegs 'n eie religieuse tradisie (teenoor alle ander religieuse tradisies) waar is, en/of as die standpunt dat religieuse "vrede" slegs deur "... the one true (state) religion" (1991a:78) gewaarborg word. Die essensialistiese benadering noem hy weer "the strategy of playing down differences" (Küng 1991a:79) en formuleer dit as die standpunt dat die "eksistensiële" probleem rondom "waarheid" nie regtig bestaan nie "... since each religion is equally true in its own way, in its essence" (Küng 1991a:79), en/of as die standpunt dat vrede tussen religieuse gemeenskappe ten beste bereik sal word deur die verskille tussen godsdienste te ignoreer. Die inklusivisiese benadering noem Küng die "omarmingsstrategie" (1990a:32) en formuleer dit as die standpunt dat slegs 'n eie godsdiens waar is, maar dat alle ander godsdienste in 'n mindere of meerdere mate deel het in die waarheid van hierdie godsdiens, en/of as die standpunt dat vrede tussen godsdienste ten beste deur die integrasie van 'n eie godsdiens met ander godsdienste bereik kan word (Küng 1991a:80).

Küng verwerp elkeen van hierdie benaderings omdat dit, kortom, neerkom op òf "waarheidsfanatisme" en gevolglike onverdraagsaamheid, óf "waarheidsvergetelheid" en 'n gevolglike gebrek aan oriëntasie en "normloosheid" (1990a:28). Anders gestel, hierdie benaderings kom neer op óf die dogmatiese verabsolutering van 'n eie godsdiens ten koste van ander godsdienste (oftewel die verabsolutering van 'n eie waarheidskriterium ten koste van die waarheidskriteria van ander), óf die uiteindelike relativering van alle godsdienste. So verstaan, kan geeneen van hierdie benaderings regtig vrede bewerkstellig nie (Küng 1990a:48). Daarom vra Küng na 'n benadering tot die probleem van verskillende godsdienste se botsende aansprake op waarheid wat nóg absolutisties, nóg relativisties is, nóg op "waarheidsfanatisme", nóg op "waarheidsvergetelheid" neerkom. Of, soos hy dit stel:

Is een weg [filosofisch-theologisch] te verantwoorden, die het zowel christenen als andersgelovigen toestaat de waarheid van de andere godsdienst te accepteren, zonder de waarheid van de eigen godsdienst en daarmee de eigen identiteit prijs te geven?

(Küng 1990a:29; vgl ook 1990a:58; 1986c:xvii-xix)

Só 'n weg vind Küng (1986b:120; 1989a:29; 1991b:243; 1994b:215) in wat hy as die "kritiese ekumeniese strategie" bestempel. Hierdie strategie vereis in die eerste instansie van gelowiges om self-kritiek toe te pas, dit is om die onware en slegte in hul eie godsdiens (diachronies en sinchronies beskou) uit te wys. Hierdie kritiek berus op die besef dat die grens tussen die ware of goeie en die 


\section{Hans Küng en religieuse pluraliteit}

onware of slegte ${ }^{8}$ nie noodwendig saamval met die grens tussen 'n eie godsdiens en ander godsdienste nie, maar dat hierdie grens dwarsoor godsdienste loop. Nie alles wat in die naam van religie geleer en gedoen word, is waar en goed nie. In elke godsdiens is daar die ware en die onware, die goeie en die slegte. Geen godsdiens kan daarom bekostig om die "kritiese spieël van die wêreldgodsdienste" (Küng 1991a:82) te ignoreer nie. Anders gestel, kritiek vanuit ander religieuse tradisies op 'n eie tradisie is nie te versmaai nie (Küng 1988b:238).

\subsection{Die vraag na ekumeniese kriteria}

Die vraag is nou net: aan die hand van watter kriteria sou die ware en goeie in die verskillende religieuse tradisies onderskei kon word van die onware en slegte? Bestaan daar één stel kriteria aan die hand waarvan gelowiges uit verskillende religieuse tradisies die onderskeie tradisies sou kon evalueer? Of is die normatiwiteit van 'n religieuse tradisie die prooi van subjektiewe willekeur? Op hierdie vraag antwoord Küng dat gelowiges uit verskillende religieuse tradisies die onderskeie tradisies aan die hand van drie vrae sou kon evalueer. In die eerste plek sou gevra kon word of 'n religieuse tradisie "humaan" is. Hierdie vraag verwoord die sogenaamde "algemeen etiese kriterium". Küng skryf: "According to the general ethical criterion, a religion is true and good if, and insofar as, it is human, does not suppress or destroy humanness, but rather protects and fosters it" (Küng 1988a:245; vgl ook 1988b:240-245). In die tweede plek sou gevra kon word of 'n religieuse tradisie nog getrou bly aan sy "oorsprong" of "wese", dit is aan sy kanonieke geskrifte en gesaghebbende (heilige) figure. Hierdie vraag verwoord die sogenaamde "algemene religieuse kriterium". Sê Küng: "According to the general religious criterion, a religion is good and true if, and insofar as, it remains true to its own origin or canon: to its authentic 'essence', its authoritative scripture or personification on which it bases itself" (Küng 1988a:245; vgl ook 1988b:245-247). In die derde en laaste instansie sou 'n lid van 'n bepaalde religieuse tradisie ook ander religieuse tradisies kon evalueer in terme van kriteria wat eksklusief tot sy of haar tradisie behoort. So is 'n religie in terme van, byvoorbeeld, die spesifiek Christelike kriterium waar en goed "... if, and insofar as, in its theory and praxis it lets the spirit of Jesus Christ be felt" (Küng 1988a:245; vgl ook 1988b:248-253; 1989a:32).

Küng is die eerste om te erken dat laasgenoemde kriterium of soort kriteria (in teenstelling met bovermelde algemeen religieuse en etiese kriteria) slegs op 'n eie godsdiens van toepassing en bindend sou kon wees (binnekort meer hieroor). Maar is dit nie ook in 'n sekere mate van die ander twee kriteria waarna hy verwys waar nie? Is die "etiese kriterium" en "religieuse kriterium" wel

\footnotetext{
${ }^{8}$ In soverre dit religie betref, val die vraag na wat "waar" en "onwaar" is vir Küng saam met die vraag na wat "goed" en "sleg" is (Küng 1988a:238-239).
} 
so "algemeen" soos Küng veronderstel? Sou gelowiges uit verskillende religieuse tradisies hulle wel gesamentlik op hierdie kriteria kon beroep ter evaluering van die waarheid van die onderskeie tradisies?

\title{
2.2.1 Die etiese kriterium
}

Dat Küng se "etiese kriterium" nie sonder meer as "algemeen" bestempel kan word nie, lê voor die hand. Gelowiges uit verskillende religieuse tradisies is dit beslis nie heeltemal met mekaar eens oor wat die woordjie "humaan" presies beteken nie. Küng is wel hiervan bewus. Daarom vra hy:

\begin{abstract}
Maar kennen we met deze theorie het humanum niet een soort rechtersfunctie toe inzake de godsdiensten, die toch op het absolute stoelen? Bouwen we op die manier niet over de concrete godsdiensten een soort "superstruktuur" heen, volgens welke die godsdiensten nu beoordeeld en veroordeeld moeten worden? Is het "humanum" - een resultaat van het Europese, christelijk beïnvloede humanisme - niet een typisch westers criterium, dat voor de oosterse godsdiensten helemaal niet van toepassing is? Is het "humanum" als oecumenisch gemeenschappelijk criterium niet al bij voorbaat te vaag, om voor de godsdiensten bindend te kunnen zijn? En is er bij een dergelijk criterium niet sprake van een vicieuze cirkel?
\end{abstract}

(Küng 1990a:44)

Hierop antwoord Küng kortom as volg:

Niet in het minst. Maar wel zijn er twee elkaar dialectisch beïnvloedende begrippen: (1) Ware menselijkheid is de voorwaarde voor ware godsdienst! Dat wil zeggen: Het humanum (eerbied voor menselijke waarde en menselijke grondwaarden) wordt in ieder geval geëist van iedere godsdienst. Op zijn minst humaniteit (dat is een minimum vereiste) moet aanwezig zijn, waar men echte godsdienstigheid wil realiseren. (2) Ware godsdienst is vervolmaking van ware menselijkheid! Dat wil zeggen: godsdienst als uitdrukking van alomvatende zingeving, van hoogste waarden en onvoorwaardelijke verplichting, is de optimale voorwaarde voor de verwezenlijking van het humanum. Juist de godsdienst, dat is het hoogste vereiste, moet daar zijn, waar men humaniteit vanuit een onvoorwaardelijke en universele verplichting wil realiseren.

(Küng 1990a:44-45) 


\section{Hans Küng en religieuse pluraliteit}

Wat Küng hier sê, is allermins klinkklaar. Die eerste punt van sy verduideliking van die "dialektiese" verhouding tussen die "humanum" of "algemeen etiese kriterium" en godsdiens lui dat "ware menslikheid" 'n "minimum vereiste" vir "ware godsdiens" is. Die vraag is nou egter: bedoel Küng hiermee dat 'n bepaalde godsdiens eers as "waar" bestempel sou kon word indien dit "humaan" is, of bedoel hy dat 'n betrokke lewensvorm eers met reg as 'n "godsdiens" bestempel sou kon word indien dit "humaan" is (dit wil sê, afgesien van die vraag of dit 'n "ware" godsdiens is)? Anders gestel, is 'n religieuse tradisie (bloot) "onwaar" wanneer en in soverre dit nie "humaan" is nie, of hou dit in sodanige gevalle op om "religie" te wees? Indien Küng laasgenoemde sou bedoel, dan berus sy aanspraak dat die "etiese kriterium" in die "algemeen" ter evaluering van godsdienste gebruik sou kon word, duidelik wel op 'n "vicieuze cirkel". Eers definieer hy godsdiens in terme van die "humanum" en dan beroem hy hom op die feit dat die "humanum" in die "algemeen" ter evaluering van godsdienste gebruik kan word omdat dit aansluiting vind by iets wat alle godsdienste in gemeen het! Dat Küng nie in hierdie slaggat trap nie, blyk egter duidelik uit uitsprake soos: "... religion is not automatically, in any and all ways, 'moral' ..." (Küng 1988a:240), en: "Religion has always shown itself most persuasive precisely where ... it has succeeded in effectively realizing the humanum ..." (Küng 1988a:240). Hier onderskei Küng wel duidelik tussen, enersyds, die "religieskap" van 'n betrokke lewensvorm en, andersyds, die "humaniteit" daarvan. So verstaan, hou 'n betrokke religie nie op om religie te wees wanneer dit nie "humaan" is nie. Dit word bloot "onware" religie.

Hiermee het Küng egter nog nie gesê waarom die "humanum" nie wel beskou kan word as "een typisch westers criterium, dat voor de oosterse godsdiensten helemaal niet van toepassing is" nie, of waarom die "humanum" nie inderdaad al by voorbaat te vaag is om as 'n "oecumenisch gemeenschappelijk criterium" te dien nie. Die tweede punt van Küng se verduideliking van die "dialektiese" verhouding tussen die "humanum" en godsdiens maak dit trouens moeilik om in te sien hoe die "humanum" wel as 'n algemene kriterium ter evaluering van die waarheid van godsdienste sou kon funksioneer. Hierdie punt lui dat godsdiens die "vervolmaking van ware menslikheid" is. Hiermee bedoel Küng dat die morele imperatief om "humaan" te wees, slegs as 'n religieuse imperatief onvoorwaardelik en universeel bindend sou kon wees. Of, soos hy dit stel: "... only the Unconditioned can oblige unconditionally; only the Absolute can bind absolutely. Only religion can establish an unconditioned and universal ethos, and at the same time concretize it ..." (Küng 1988a:241). Let egter op die laaste sinsnede van hierdie uitspraak (dit is “... and at the same time concretize it ..."). Deur hierdie sinsnede aan die voorafgaande toe te voeg, gee Küng erkenning aan 'n belangrike punt wat die veronderstelde "algemeen- 
heid" van sy etiese kriterium ondermyn en wat hy daarom hier nie genoeg beklemtoon nie. Die punt is dat verskillende religieuse tradisies nie die "humanum" op presies dieselfde wyse "verkonkretiseer" nie. Gelowiges uit veral die Oosterse religieuse tradisies sou hul inderdaad nie sonder meer met Küng se etiese kriterium (wat, soos hy self toegee, “... een resultaat van het Europese, christelijk beïnvloede humanisme ..." is) kon vereenselwig nie (vgl ook Cowdell 1989:91). Verder is daar duidelik ook religieuse tradisies wat hoegenaamd nie beoog om in enige voorstelbare of betekenisvolle sin van die woord "humaan" te wees nie (bv Satanisme).

Dit ten spyt, is Küng nietemin hoopvol dat gelowiges uit verskillende religieuse tradisies uiteindelik wel konsensus sal kan bereik oor wat, en wat nie "humaan" is nie: "... there is reasonable hope that a foundational consensus on the 'basic premises of human life and living together'... among the world religions can be built on the heights of modern, humane mentality" (1988a:241). Let egter op dat Küng hoop dat bovermelde konsensus via 'n "moderne, humane mentaliteit" bereik sal kan word. Hierdie mentaliteit omskryf hy elders as “... a secularist humanism critical of religion ..." (Küng 1988a:240). Maar, só verstaan, kan die konsensus waarvoor Küng hoop beswaarlik as 'n interreligieuse konsensus bestempel word. Dis eerder 'n konsensus ten spyte en ten koste van religie. Die "[unmistakeable] progress in the direction of humaneness within the various religions ..." wat Küng (1988a:241) bespeur, is daarom misleidend en bied nie sonder meer rede om te glo dat die "humanum" tog wel eendag as 'n algemene etiese kriterium "... that holds for all religions" (Küng 1988a:243) sal kan funksioneer nie. Die progressie wat Küng bespeur, sou immers ook interpreteer kon word as ' $n$ "unmistakeable, modern progress in the direction of humaneness in spite of the various religions".

\subsubsection{Die religieuse kriterium}

Dit bring my by Küng se sogenaamde "algemene religieuse kriterium". Hy skryf:

There is a general religious criteriology: a religion can be measured against its authoritative teaching or practice (Torah, New Testament, Qur'àn, Vedas, or Gita), and in some instances against an authoritative personification (Christ, Muhammad, Buddha). This criterion of "authenticity" or "canonicity" can therefore be applied to all the great religions - mutatis mutandis, of course: adapted to each religion, more easily to some (e.g. Islam) than to others (e.g. Hinduism). 


\section{Hans Küng en religieuse pluraliteit}

Waar die "humanum" beswaarlik as 'n algemene, ekumeniese kriterium kwalifiseer, kan die religieuse kriterium hier ter sprake myns insiens inderdaad wel met veel groter vrymoedigheid as "algemeen", oftewel as "toepasbaar en bindend op alle religieuse tradisies" bestempel word. Küng se aanspraak dat die "humanum" 'n algemene, ekumeniese kriterium konstitueer, rus swaar op die voorveronderstelling dat die verskillende godsdienste 'n bepaalde inhoudelike ooreenkoms vertoon. Soos ons gesien het, voorveronderstel hierdie aanspraak naamlik dat al die verskillende godsdienste leer dat "menslikheid" (soos gedefinieer deur 'n Europese, Christelik-beïnvloede humanis) beskerm en bevorder moet word. Hierteenoor berus die "algemeenheid" van die "religieuse kriteriologie" nie op die veronderstelling dat die verskillende godsdienste 'n bepaalde inhoudelike ooreenkoms vertoon nie, maar op 'n bepaalde formele (en, in hierdie sin, meta-religieuse) ooreenkoms tussen godsdienste wat Küng tereg identifiseer.

Dit is egter moeilik om in te sien hoe 'n "criterion of 'authenticity"' ter beoordeling van die waarheid van 'n bepaalde religieuse tradisie (vis-à-vis ander religieuse tradisies) gebruik sou kon word. Dit sou wel gebruik kon word om, byvoorbeeld, te besluit of ' $n$ tradisie wat sigself as "Christelik" voordoen, wel in teorie en praktyk "waarlik" (lees: "eg") Christelik is, ensovoorts. Dit sou egter duidelik nie gebruik kon word om te besluit of 'n religieuse tradisie wel gelyk het in sy aanspraak op waarheid nie. Daar is immers 'n duidelike verskil tussen die oordeel dat 'n betrokke religieuse tradisie (byvoorbeeld) "ware Hindoeïsme" is, en die oordeel dat Hindoeïsme "waar" is.

Hierop sou Küng antwoord dat die verskil tussen die oordeel dat 'n religie, byvoorbeeld, "ware Hindoeïsme" is en die oordeel dat 'n religie "waar" is, nie in die oë van die Hindoe self geld nie. Vir die Hindoe val "true Hinduism" en "true religion" saam. Of, soos Küng (1988a:244 - my beklemtoning) dit stel:

True Hinduism [dit is outentieke Hindoeïsme] is in principle only the religion based on the revealed writings of the Vedic seer [dit is die kanon van Hindoeïsme]. Thus, ... because Buddhism (as also Jainism) rejected the Vedas, it cannot for Hindus be the true religion and is therefore rejected, as is also Indian Islam.

Dit wat Küng hier sê, impliseer nie bloot dat die sogenaamde "kriterium van outentisiteit of kanonisiteit" hopeloos te relatief is om enigsins te dien ter beslegting van die probleem van verskillende godsdienste se botsende aansprake op waarheid nie. Dit impliseer eerder dat die "kriterium van outentisiteit of kanonisiteit" heeltemal irrelevant ten opsigte van hierdie probleem 
is. Hierdie kriterium het slegs betrekking op die waarheid van religieuse tradisies wanneer dit op 'n eie religieuse tradisie toegepas word. Wanneer die Christen byvoorbeeld vra of haar godsdiens nog met die Christelike kanon (dit is die Bybel, veral die Nuwe Testament) strook, dan oordeel sy nie bloot oor die outentisiteit van haar godsdiens nie, maar ook oor die waarheid van haar godsdiens. Vir die Christen val dit wat outentiek Christelik is, immers saam met dit wat waar is. Wanneer die Christen nou egter dieselfde kriterium (dit is koherensie met die kanon) mutatis mutandis op 'n ander godsdiens sou toepas, dan verdwyn die relevansie van hierdie kriterium in soverre dit die waarheid van religieuse tradisies betref. Aan die hand van hierdie kriterium sou die Christen wel kon oordeel of die ander godsdiens outentiek Islam, Judaïsme, Boeddhisme (of wat die geval ook mag wees) is, maar die toepassing van hierdie kriterium sou haar niks oor die waarheid van die ander godsdiens kon leer nie.

Küng se "algemene religieuse kriterium" sou egter ook anders geïnterpreteer kon word sodat dit wel relevant ten opsigte van die probleem van verskillende godsdienste se botsende aansprake op waarheid sou kon wees. Let op die volgende uitspraak: "Christians measure themselves against their origin [dit is die Christelike kanon]. However, they are often also so measured by non-Christians: "You appeal to the Bible, to Christ - and behave thus" (Küng 1988a:243)?

Die waarneming van die nie-Christene wat hier aan die woord is, naamlik dat die betrokke Christene wat hul kritiseer nie volgens die Christelike kanon leef nie, sou tot twee konklusies kon lei. Dit sou eerstens kon lei tot die konklusie dat die religie van genoemde Christene nie outentiek Christelik is nie. Hierdie konklusie sê egter nog absoluut niks oor die waarheid van die religie van die betrokke Christene nie. Of, meer presies, vir die nie-Christene sê hierdie konklusie niks oor die waarheid van die religie van die Christene hier ter sprake nie. Vir die Christene sou die konklusie dat hul religie nie outentiek Christelik is nie, egter wel (soos verduidelik) beteken dat dit nie waar is nie.

Bovermelde waarneming van die nie-Christene (resp. "You appeal to the Bible, to Christ - and behave thus?") sou egter ook tot 'n ander konklusie kon lei. Die nie-Christene sou naamlik ook kon konkludeer dat die religie van die Christene hier ter sprake nie koherent of kongruent is nie. So verstaan, val die klem nie soseer op die feit dat die betrokke religie nie met die relevante kanon kohereer nie, maar eerder op die feit dat die betrokke religie nie koherent of kongruent is nie. Anders gestel, die kriterium in die lig waarvan hierdie konklusie bereik word, is nie soseer ' $n$ "kriterium van kanonisiteit of outentisiteit" nie, maar eerder 'n kriterium van koherensie of kongruensie. In soverre die waarheid van 'n religie wel met die koherensie of kongruensie daarvan verband hou, is Küng se "criterion of authenticity or canonicity" in hierdie gekwalifiseerde sin (dit is as 


\section{Hans Küng en religieuse pluraliteit}

'n kriterium van koherensie of kongruensie) wel relevant ten opsigte van die probleem van verskillende godsdienste se botsende aansprake op waarheid. 'n Interessante en belangrike vraag wat op hierdie punt ontstaan, is of die kriterium van koherensie of kongruensie wel as toepasbaar en bindend op alle religieuse tradisies beskou sou kon word. Ruimte laat my nie toe om dié vraag hier aan te spreek nie (vgl egter Louw 2004b:304-310). Nietemin, toepasbaarheid en bindendheid op alle religieuse tradisies geld beslis nie die derde en laaste kriterium (oftewel soort kriteria) in terme waarvan die waarheid van 'n religieuse tradisie volgens Küng beoordeel sou kon word nie.

\subsubsection{Eiesoortige kriteria}

Volgens Küng sou 'n lid van 'n bepaalde religieuse tradisie ook ander religieuse tradisies kon evalueer in terme van kriteria wat eiesoortig aan sy of haar tradisie is. ' $n$ Christen sou byvoorbeeld kon vra of 'n bepaalde religieuse tradisie wel versoenbaar is met die leer en lewe van Jesus Christus, ensovoorts. Alhoewel hierdie soort kriteria slegs (met reg) op 'n eie godsdiens van toepassing en bindend sou kon wees, sou geen gelowige volgens Küng daarvan kon afsien om die waarheidskriteria wat spesifiek tot sy of haar eie religieuse tradisie behoort, ook op ander religieuse tradisies toe te pas nie. So iets sou op 'n verlies aan eie identiteit of "selfverloëning" (Küng 1990a:37) neerkom en tewens 'n interreligieuse dialoog oor die waarheid van religieuse tradisies onnodig maak. Of, soos Küng dit stel: "Actually, no dialogue would be needed if there was nothing normative or definitive anymore in anyone's religion. Put differently: the virtue of dialogability needs the virtue of steadfastness (not statically but dynamically understood). Both virtues belong together" (Küng 1991b:247; vgl ook 1991b:246, 249). ${ }^{9}$

Küng het dit hier spesifiek oor die houding wat die Christen behoort in te neem in 'n interreligieuse dialoog oor die waarheid van religieuse tradisies. Die sogenaamde "virtue of steadfastness" waarna hier verwys word, omskryf Küng as "... holding fast in faith to the Christian issue, unbribable and without fear of reprisals" (Küng 1991b:248). ${ }^{10}$ Let op dat hy van mening is dat hierdie "deug" nie staties nie, maar dinamies verstaan moet word. Dit herinner sterk aan die

\footnotetext{
${ }^{9}$ Vergelyk in hierdie verband ook Küng $(1998: 108)$ se begrip van “... autonomous selfrealization with responsibility in solidarity ...", oftewel "... a way between a modernism without foundations and a fundamentalism without modernity, ... between permissiveness and exclusiveness, between laxity and aggressiveness" (Küng 1992:124).

${ }^{10}$ Küng skryf: "... [theology] is therefore not a question of a new invention of a tradition. It is a question of a new formulation of tradition, admittedly in the light of a new paradigm" (aangehaal deur Rhem 1986:245; vergelyk ook Küng 1988b:154, 209-226; 1990c:42-51). Vergelyk ook: “... we cannot change a fundamental attitude in life as we might change a coat" (Küng 1987:60).
} 
standpunt van die bekende Proses-teoloog en filosoof, John B Cobb (jr). Cobb verwag nie van Christene om hul eiesoortige norme by voorbaat of "apriories" (Küng se term) ${ }^{11}$ prys te gee nie, maar wel om hul eiesoortige norme in die lig van die norme van ander gelowiges te hersien en te verruim (Louw 2004a:322). In sy opsomming van wat hy as 'n "dialogue in steadfastness" (Küng 1991b:248) en as ' $n$ “... maximal theological openness toward other religions" (Küng 1988a:250) bestempel, erken Küng trouens dat hy op hierdie punt heelwat van Cobb geleer het:

... out of a truly Christian commitment and in continuous eagerness to learn, we should transform ourselves ever new on our way; we should let ourselves be transformed by the newly learned, so that the old belief will not be destroyed, but enriched. This is "the way of creative transformation" (John Cobb), the way of the Christian faith as challenged by the ecumenical commitment.

(Küng 1991b:248) ${ }^{12}$

\subsection{Christenskap en "maksimale openheid"}

Cobb wil graag glo dat bovermelde "weg van kreatiewe transformasie" tot 'n "truly global theology" lei (Louw 2004a:5). Hierdie opvatting resoneer met die veronderstelling by Küng dat sy "kritiese ekumeniese strategie" (oftewel "dialogue in steadfastness") 'n "maksimale (dit is 'onbeperkte') ${ }^{13}$ teologiese openheid teenoor ander godsdienste" konstitueer. Vir die meeste kompetente gebruikers van die adjektiewe "maksimaal" of "onbeperk", beteken hierdie terme (kortom) "die hoogste" of "die grootste denkbare". So verstaan, beteken "maksimale teologiese openheid teenoor ander godsdienste" (binne die konteks van 'n interreligieuse dialoog oor die waarheid van religieuse tradisies) duidelik nie dat - soos Küng dit wil hê - die Christen sy of haar Christelike oortuigings bloot moet aanpas of "kreatief" moet "transformeer" in die lig van kritiek uit ander godsdienste nie. Dit beteken eerder die bereidheid (in beginsel) om, indien nodig, sy of haar Christenskap in die lig van sodanige kritiek volledig te laat vaar (Cobb 1984:174-175).

\footnotetext{
${ }^{11}$ Küng (1991b:246).

12 Die "weg van kreatiewe transformasie" waarna Küng (1990c:155, 169) hier verwys, word ook weerspieël in sy visie vir 'n "toekomstige kerk" en 'n "beter toekoms."

${ }^{13}$ Küng (1990a:52).
} 
Hans Küng en religieuse pluraliteit

\subsubsection{Die fideïstiese strategie}

Hierop antwoord Küng dat dit onrealisties is om só 'n bereidheid van die Christen (of enige ander gelowige) te verwag, aangesien iemand se religie meer is as bloot ' $n$ "sisteem" wat "intellektueel" geassimileer en gekritiseer kan word:

... Christianity, like every other religion (unlike philosophy), is at once a message of salvation and a way of salvation. I encounter there not simply a philosophico-theological argumentation that demands my reflection, but rather a religious provocation, and in the case of Christianity, a prophetical message that calls for a completely personal taking of a stand, a following. Only thus does one directly understand this religion in all its depth.

(Küng 1988a:245-246) ${ }^{14}$

Küng klink hier soos ' $n$ relativis of, meer spesifiek, ' $n$ fideïs. ${ }^{15}$ Op die oog af wil dit immers voorkom asof hy hier aanvoer dat die normatiwiteit of waarheid van 'n bepaalde religieuse tradisie slegs of eksklusief vir die lede van daardie tradisie geld. Hierbenewens stel hy dit duidelik dat 'n religieuse tradisie ten diepste slegs via 'n (eksistensiële) "commitment" begryp kan word (waarmee in effek gesê is dat ' $n$ religieuse tradisie ten diepste slegs deur die lede daarvan verstaan kan word). Die indruk dat Küng hom hier tot 'n fideïstiese strategie wend, word versterk deur uitsprake soos:

Only when a religion has become my religion does the discussion about the truth reach its deepest depths. Truth for me, therefore, means my faith, just as for the Jew and the Muslim, Judaism and Islam, and for the Hindu and the Buddhist, Hinduism and Buddhism, are their religion, their faith, and thereby the truth. My religion, and also the other religions, are concerned not about a general, but an existential truth: tua res agitur. In this sense there is - for me as for all other believers - only one true religion.

(Küng 1988a:246)

\footnotetext{
${ }^{14}$ Vergelyk ook: "... no religion can be grasped in its deepest reality if one has not affirmed it from within, with ultimate existential seriousness" (Küng 1988a:246).

15 ' $n$ "Fideïs" is van mening dat die betekenis en waarheid van 'n bepaalde religieuse diskoers slegs sal blyk aan diegene wat daarin partisipeer, resp. aan die "ingewydes" (Louw 1997:9495).
} 
Hierdie uitsprake klop in geen voor-die-hand-liggende sin met die "kritiese ekumeniese diskussie" wat Küng ter beslegting van die "waarheidsvraag" en gevolglike bereiking van wêreldvrede in die vooruitsig stel nie. Om mee te begin, sou die diskussie hier ter sprake immers slegs kon geluk indien die lede van die verskillende religieuse tradisies mekaar wel verstaan, oftewel indien interreligieuse kommunikasie wel moontlik is. Die veronderstelling by Küng dat 'n religieuse tradisie "ten diepste" slegs deur die lede daarvan verstaan kan word, maak sodanige kommunikasie egter onmoontlik (of, in ieder geval, "ten diepste" onmoontlik). Verder (en hierdie punt sluit ten nouste by die vorige aan) vereis genoemde veronderstelling dat diegene wat die "kritiese, ekumeniese diskussie" "[at] its deepest depths" wil voer, lede sal word van die religieuse tradisie waarvan die waarheid ter diskussie is. Hulle sou immers slegs só hierdie tradisie "ten diepste" kon verstaan (of, altans, so lui die veronderstelling). Hiermee word egter effektief vereis dat die deelnemers aan bovermelde "kritiese, ekumeniese diskussie" die religieuse tradisie wat ter diskussie is by voorbaat as "waar" moet beoordeel. So 'n vereiste maak duidelik nie sin nie. Die diskussie hier ter sprake handel immers juis oor die waarheid van religieuse tradisies. Dit sou wel sin maak om te vereis dat die deelnemers aan hierdie diskussie die betrokke religieuse tradisies ten diepste begryp of verstaan voordat hulle 'n oordeel oor die waarheid daarvan waag. ${ }^{16}$ In die derde plek lê die "deepest depths" wat 'n diskussie oor die waarheid van 'n religieuse tradisie volgens Küng sou kon bereik op 'n "persoonlike", "eksistensiële" of (wat ek wil noem) "commitment"-vlak, dit is 'n vlak waarop daar vir Küng “... as for all other believers ..." slegs één ware religie sou kon wees. Maar, só verstaan, sou hierdie diskussie in geen voor-die-hand-liggende sin van die woord "krities" kon wees nie. 'n "Kritiese" beoordeling van die waarheid van 'n religie vereis immers dat die legitimiteit van die betrokke religie se aanspraak op waarheid voorlopig opgeskort of tussen hakies geplaas word, en dat die beoordelaar as't ware afstand inneem ten opsigte van die religie wat beoordeel word.

Küng wend hom egter nie net tot fideïstiese strategieë in sy poging om aan te toon dat die implementering van die spesifiek Christelike kriterium van waarheid wel met 'n "maksimale teologiese openheid teenoor ander godsdienste" versoenbaar is nie. Twee ander strategieë word ook ingespan.

\footnotetext{
${ }^{16}$ Behalwe natuurlik as 'n mens sou veronderstel dat die waarheid van 'n religieuse tradisie met die begryplikheid of verstaanbaarheid daarvan saamval (Louw 2000a:257).
} 


\title{
2.3.2 Die "objektiwiteit" van die Christelike kriterium
}

Om mee te begin, probeer Küng aantoon dat die spesifiek Christelike kriterium vir waarheid nie heeltemal so arbitrêr of relatief is soos hy aanvanklik wou voorgee nie. ${ }^{17}$ Küng probeer hierdie konklusie langs twee weë bereik.

\subsubsection{Die Christelike kriterium en "rasionele verantwoordelikheid"}

In die eerste plek voer hy aan dat sy "decision of faith" (Küng 1988a:247) om die normatiwiteit van die Christelike religieuse tradisie te erken, nie "bloot" willekeurig is nie, maar op gronde berus wat ook die lede van ander religieuse tradisies sal oortuig:

\begin{abstract}
A reasonable trust, this decision of faith is in no way purely subjective and arbitrary, but is rationally responsible ... If we do not wish to simply hide behind a dogmatic postulate, we cannot as Christians shirk the effort to give a substantive, empirical grounding for the significance of Jesus Christ.
\end{abstract}

(Küng 1988a:247-248; vgl ook 1988b:201-203)

Met die eerste lees wil dit voorkom asof Küng hier sê dat hy wel in beginsel bereid is om sy geloof in die normatiwiteit van die spesifiek Christelike kriterium vir waarheid te laat vaar indien dit nie op oortuigende gronde teenoor die lede van ander religieuse tradisies verantwoord kan word nie. Só verstaan, sou sy benadering tot die probleem van verskillende godsdienste se botsende aansprake op waarheid wel met reg as 'n "maksimale" openheid jeens ander religieuse tradisies bestempel kon word. Let egter op dat Küng van mening is dat sy keuse vir die Christelike religieuse tradisie en die spesifiek Christelike kriterium vir waarheid ${ }^{18}$ nie bloot of "purely" subjektief en arbitrêr is nie. Hiermee is egter ook gesê dat dié keuse wel tot 'n mate subjektief en arbitrêr is (vgl ook Küng 1987:28, 35-36, 64; 1990c:152). Hierdie punt strook met sy opvatting dat die keuse vir 'n bepaalde religie nie uitsluitlik 'n kwessie van "philosophicotheological argumentation that demands my reflection" (Küng 1988a:245; vgl ook 1989a:25) is nie, maar dat dit ook 'n "taking of a stand" met "ultimate existential seriousness" behels (Küng 1988a:246). Dit strook ook met 'n

\footnotetext{
${ }^{17}$ Vergelyk: "... one must be clear about the fact that these criteria [i e the specific (Christian, Jewish, Islamic, Hindu, Buddhist) criteria of truth] first of all can be relevant and indeed binding only for oneself, not for the others" (Küng 1988a:239).

${ }^{18}$ Küng (1988a:247) omskryf hierdie keuse ook as 'n "... decision [of faith] for the one God who is ... finally and ultimately the 'God of Jesus Christ' (the God of the Christians) ...."
} 
opmerking wat hy per geleentheid teenoor Knitter gemaak het. Laasgenoemde sê:

... Küng has told me personally, and has said so publicly, that although to move in the direction of a nonabsolutist christology might make logical sense, he himself could not make this move, mainly for two reasons: it would alienate him from his faith community and it would tend to diminish the depth and firmness of Christians' personal commitment to Jesus Christ.

(Knitter 1987:194-195)

Uit Küng se opmerking teenoor Knitter kan afgelei word dat eersgenoemde se aanspraak dat sy keuse vir die Christelike religieuse tradisie nie "suiwer" subjektief en arbitrêr is nie, nie vir hom beteken dat hierdie keuse daarom volledig "rationally responsible" is nie. Hierdie keuse berus volgens Küng "ten diepste" op 'n persoonlike "commitment" waarvan die "depth and firmness" onaangetas moet bly. Soos verduidelik, moedig Küng wel saam met Cobb die "kreatiewe verruiming" van die spesifiek Christelike kriterium (in die lig van die eiesoortige norme van ander religieuse tradisies) aan. Hiermee het hy hom egter nog geensins bereid verklaar om die spesifiek Christelike kriterium in die lig van weerleggende "substantiewe, empiriese" getuienis prys te gee nie. My punt is nie dat die keuse vir 'n bepaalde religieuse tradisie nie wel as 'n "commitment" bestempel sou kon word, of dat sodanige "commitment" in die lig van "substantiewe, empiriese" getuienis hersien sou kon word nie. My punt is slegs dat Küng - gegee sy "commitment" tot die spesifiek Christelike kriterium vir "true religion" - nie met reg sy houding jeens ander religieuse tradisies as 'n "maksimale openheid" sou kon bestempel nie. Deur sy benadering tot ander religieuse tradisies só te etiketteer, onderbeklemtoon Küng 'n belangrike feit. Hierdie etiket onderbeklemtoon naamlik die feit dat die "interreligieuze verzoening" en "groeiende oecumenische gemeenschap" (Küng 1990a:52) wat op Küng se "kritiese ekumeniese diskussie" sou kon volg, grense het. Tot sover Küng se eerste poging om aan te toon dat die spesifiek Christelike kriterium vir waarheid nie heeltemal so arbitrêr of relatief is soos dit op die oog af mag lyk nie.

\subsubsection{Die Christelike kriterium en die "humanum"}

Vervolgens probeer hy om dieselfde punt te maak deur aan te voer dat genoemde kriterium in der waarheid met die "algemeen etiese kriterium" (oftewel die "humanum") saamval: 
At what ... does the Sermon on the Mount, the entire moral teaching of Jesus, aim? At nothing more than a new, true humanity: the Sabbath, the commandments, are for the sake of humanity, and not the other way around ... This means that the more human Christianity is (in the spirit of the Sermon on the Mount), the more Christian it is; and the more Christian it is, the more it will also outwardly appear as true religion.

(Küng 1988a:248). ${ }^{19}$

Die argument wat Küng hier ter ondersteuning van die "objektiwiteit" van die spesifiek Christelike kriterium vir ware religie voer, sou alleen geldig kon wees indien: (a) die sogenaamde "algemeen etiese kriterium" inderdaad so algemeen (dit is universeel-geldend en bindend) is soos Küng beweer; en (b) die spesifiek Christelike kriterium inderdaad met hierdie "algemeen etiese kriterium" saamval. Hierbo is egter reeds gekonkludeer dat (a) nie die geval is nie. Küng se "algemeen etiese kriterium" is eerder die produk van 'n moderne, Europese, sekulêre mentaliteit en kan as sodanig allermins met reg as toepasbaar en bindend op (alle) religieuse tradisies beskou word. Hiermee is egter ook reeds gesê dat (b) nie die geval is nie. Bovermelde mentaliteit is en word weliswaar deur Christelike oortuigings beïnvloed, maar is beswaarlik resloos die produk van die Christelike religieuse tradisie. Soos Byron Lambert (1990:163) tereg opmerk:

It is clear Küng cannot understand at least one strand of New Testament theology if he thinks the Sermon on the Mount is humane. It is true that in the opening beatitudes certian qualities of life, like poverty of spirit, meekness, and purity of heart are praised, but thereafter the severest burdens of discipleship are imposed on the believer, even to the climactic, "Be ye perfect, even as your Father in Heaven is perfect". "Humane" for whom?

\subsubsection{Die "interne-eksterne" verhouding}

Dit bring my by die derde en laaste strategie van Küng om aan te toon dat die implementering van die spesifiek Christelike kriterium van waarheid wel met 'n "maksimale teologiese openheid teenoor ander godsdienste" versoenbaar is. Küng beroep hom in die laaste instansie op 'n beproefde filosofiese grondbeginsel wat lui dat kontradiksies met behulp van betekenisonderskeidings uit die weg geruim kan word. Die kontradiksie wat hier ter sake is, is dié tussen,

\footnotetext{
${ }^{19}$ Vergelyk ook: "... humanity certainly finds its proper justification and foundation only in the humanity of God, revealed in Jesus Christ" (Küng 1989b:449; vgl ook 1976:249, 530, 554).
} 
enersyds, "... [a] special commitment to the Christian message, tradition, or community ..." (Küng 1988a:245) en, andersyds, 'n "... maximal theological openness toward other religions" (Küng 1988a:250). Om hierdie kontradiksie uit die weg te ruim, onderskei Küng tussen twee perspektiefpunte van waaruit een en dieselfde individu syns insiens die waarheid van religieuse tradisies sou kon beoordeel. In die eerste plek sou 'n bepaalde individu as 'n lid van 'n spesifieke religieuse tradisie die waarheid van religieuse tradisies kon beoordeel. Vanuit hierdie perspektief is slegs een religieuse tradisie waar, te wete die spesifieke religieuse tradisie waarvan genoemde individu ' $n$ lid is. Dieselfde individu sou nou egter ook volgens Küng as 'n "neutrale" waarnemer oor die waarheid van religieuse tradisies (insluitende sy/haar eie) kon oordeel. Vanuit hierdie perspektief sou baie godsdienste as "waar" beoordeel kon word, afhangende van die mate waarin godsdienste voldoen aan die vereistes soos voorgeskryf deur die "algemeen etiese kriterium" en "algemeen religieuse kriterium" vir waarheid (Küng 1988a:245, 249; 1988b:254).

In terme van die onderskeid wat Küng hier maak, sou hy inderdaad met reg daarop kon aanspraak maak dat sy "commitment" tot die Christelike religieuse tradisie nie ' $n$ "maksimale" openheid tot ander religieuse tradisies uitsluit nie. Die vraag is nou egter: is dit wel vir een en dieselfde persoon moontlik om tegelykertyd lid van 'n spesifieke religieuse tradisie én "neutrale" beoordelaar van daardie tradisie te wees? Küng (1988a:245) meen dat so 'n "external-internal relationship" wel moontlik is en verskaf die volgende analogie ter illustrasie:

When an international lawyer, for example, compares various
international constitutions with one another, or when he attempts to
arrive at an understanding of a disputed point in international
negotiations, he likewise views his national constitution (and his state)
"from outside". However, he views the same constitution (and his
state) "from within" when, as a loyal citizen, he feels himself obliged
precisely to this (and no other) constitution and holds himself bound to
it in conscience.

(Küng 1988a:245)

Die geldigheid van hierdie analogie rus (o a) swaar op die veronderstelling dat 'n religieuse "commitment" wel vergelykbaar is met die lojaliteit van 'n burger teenoor sy land en/of die nasionale konstitusie van sy land. Anders gestel, dit rus swaar op die veronderstelling dat die nasionale konstitusie van 'n betrokke land dieselfde waarde en funksie vir 'n lojale burger van daardie land het, as wat 'n bepaalde religieuse tradisie vir 'n lid daarvan het. Hierdie veronderstelling is 


\section{Hans Küng en religieuse pluraliteit}

egter, in die lig van Küng se eie begrip van religie en van 'n religieuse "commitment", duidelik onhoudbaar. Küng (1988a:246) omskryf hierdie "commitment" as 'n "... ultimate existential seriousness" (my beklemtoning) wat as sodanig nie sonder 'n fundamentele verlies aan identiteit prysgegee sou kon word nie (Küng 1990a:29). Dieselfde kan beswaarlik gesê word van die lojaliteit wat 'n burger van 'n betrokke land teenoor daardie land en/of die nasionale konstitusie van daardie land betoon. ${ }^{20}$ Küng omskryf sy "commitment" tot die Christelike tradisie en die spesifiek Christelike kriterium vir waarheid ook as 'n "... decision [of faith] for the one God - who is not only the 'God of the philosophers and sages' (the God of the Greeks), and the 'God of Abraham, Isaac, and Jacob' (the God of the Jews), but finally and ultimately the 'God of Jesus Christ' (the God of the Christians) ..." (Küng 1988a:247 - my beklemtoning). Let op die woorde "finally" en "ultimately" soos dit hier gebruik word..$^{21}$ Deur die gebruik van hierdie woorde, wys Küng op 'n belangrike funksie of eienskap van religie in terme waarvan dit vir die gelowige logies gesproke onmoontlik sou wees om 'n eie religieuse tradisie in die lig van ander tradisies te evalueer. 'n Religie konstitueer naamlik die "ultimate" (dit is die "hoogste", allesomvattende, finale en universeel-geldende) verwysingsraamwerk of waardehorison in terme waarvan die gelowige die sin, betekenis en waarheid van alles (insluitende alle ander verwysingsraamwerke of waardehorisonne) in die laaste instansie beoordeel. Dit kan egter beswaarlik van die konstitusie van 'n betrokke land gesê word dat dit die "ultimate" verwysingsraamwerk of waardehorison van 'n burger van daardie land konstitueer. Die feit dat dit vir 'n internasionale regsgeleerde moontlik is (as dit inderdaad is) om tegelykertyd lojaal aan die konstitusie van sy land te bly én dieselfde konstitusie in die lig van ander konstitusies te kritiseer, beteken dus nog nie dat so iets (mutatis mutandis) ook vir 'n gelowige moontlik is nie. Küng slaag dus ook nie met behulp van hierdie analogie daarin om aan te toon dat sy "commitment" tot en implementering van die spesifiek Christelike kriterium van waarheid wel met 'n "maksimale teologiese openheid teenoor ander godsdienste" versoenbaar is nie.

\footnotetext{
${ }^{20}$ Tensy hierdie lojaliteit "quasi-religieuse" proporsies begin aanneem (Küng 1986a:xiv).

${ }^{21}$ Vergelyk ook: "Religion is a believing view of life, approach to life, way of life, and therefore a fundamental pattern embracing the individual and society, man and the world, through which a person (though only partially conscious of this) sees and experiences, thinks and feels, acts and suffers, everything" (Küng 1986c:xvi); "We all have a personal God: a supreme value by which we regulate everything, to which we orientate ourselves, for which if need be we sacrifice everything" (Küng 1987:29 - my beklemtoning); “... religion offers an ultimately comprehensive meaning of life and death, proclaims a highest, indestructible value, sets unconditionally binding standards ..." (Küng 1988a:238 - my beklemtoning).
} 


\section{KONKLUSIE}

Sowel die eerste as tweede fase van Küng se benadering tot religieuse pluraliteit spreek van 'n begeerte om nie-Christelike godsdienste te akkommodeer. Die vroeëre Küng vervang die ekklesiosentrisme van Rahner met wat hy as "teosentrisme" bestempel. Die latere Küng, insgelyks, rig hom teen die verabsolutering van ' $n$ eie religieuse tradisie, asook die identifisering van "essensies" of "gemene delers" wat die selfverstaan van godsdienste misken, en vervang hierdie benaderings met wat hy as ' $n$ "kritiese ekumeniese strategie" bestempel. Op die keper beskou, is die benadering van nòg die vroeëre Küng, nòg die latere Küng egter so akkommoderend soos dit op die oog af mag lyk. Die "teosentrisme" van die vroeëre Küng het geblyk niks meer as 'n christosentrisme te wees nie en die "radikale openheid" van die latere Küng niks meer as 'n "committed openness" nie. Sowel die vroeëre as latere Küng bly onlosmaaklik verbonde aan die spesifiek Christelike kriterium, hoewel dit - soos die latere Küng sou wou aanvoer - deur interreligieuse dialoog "verruim" is en word. Küng se benaderings paradeer as 'n verplasing van die spesifiek Christelike kriterium, maar kom hoogstens op 'n verskuiwing in die spesifiek Christelike kriterium neer.

Is die waarheid van godsdienste en, meer spesifiek, die normatwiteit van die Christelike godsdiens vis-à-vis ander godsdienste, dus tog maar uiteindelik aan subjektiewe willekeur uitgelewer? Is 'n "uncommitted" of onbevooroordeelde evaluering van godsdienste hoegenaamd moontlik? Kan gelowiges uit verskillende religieuse tradisies hierdie tradisies aan die hand van één gemeenskaplike kriterium of stel kriteria beoordeel? Ruimte laat my nie toe om dié vrae hier behoorlik te beantwoord nie. Die objektiewe of nie-arbitrêre beoordeling van die godsdiens van ' $n$ ander vereis in die eerste plek ' $n$ behoorlike begrip daarvan, dit wil sê dit vereis dat die beoordelaar kommunikeer met diegene wat beoordeel word (Louw 2000a:255-278). Hierbenewens vereis dit ook ' $n$ beoordelingskaal waarmee alle betrokkenes hul kan vereenselwig (Louw 2000b:45-73). Kortom, die objektiewe beoordeling van godsdienste vereis 'n gemeenskaplike "taal". Hierdie "taal" is nie ' $n$ gegewe nie, maar 'n opgawe. Dit bestaan, indien hoegenaamd, op grasie van ' $n$ volgehoue blootstelling aan die ander. Dit vereis ' $n$ volgehoue bereidheid om aandagtig na hom/haar te luister om só noukeurig moontlike ooreenkomste en verskille met hom/haar te identifiseer. Die proses waarin genoemde gemeenskaplike "taal" gevorm word, kom neer op 'n wisselwerking tussen en uiteindelike versmelting van horisonne. Natuurlik impliseer die voorlopigheid en verandelikheid van die "taal" wat gelowiges praat, dit is van die terme waarin hulle die ander (en hulleself) verstaan en beoordeel, dat so 'n versmelting nie altyd sal geluk nie. Dit beteken egter ook dat so 'n 


\section{Hans Küng en religieuse pluraliteit}

versmelting nie outomaties of met voorspelbare reëlmaat sal misluk nie. Inteendeel, die voorlopigheid en verandelikheid van die "taal" van gelowiges beteken juis dat hierdie versmelting dalk op 'n dag iewers sou kon geluk (Brand 2002:35-36). Hierdie feit weerhou gelowiges van die "waarheidsfanatisme" en "waarheidsvergetelheid" waarteen Küng tereg waarsku. Oftewel, dit weerhou gelowiges daarvan om òf hul eie godsdiens dogmaties en onkrities tot die norm vir ander godsdiens te verabsoluteer, òf die evaluering van godsdienste gewoon aan subjektiewe willekeur oor te laat.

\section{Literatuurverwysings}

Brand, G 2002. Speaking of a fabulous ghost: In search of theological criteria, with special reference to the debate on salvation in African Christian Theology. Frankfurt am Main: Peter Lang.

Cobb, J B 1984. The meaning of pluralism for Christian self-understanding, in Rouner, L S (ed), Religious pluralism, 161-179. Notre Dame, IN: University of Notre Dame Press.

Cowdell, S 1989. Hans Küng and world religions: The emergence of a pluralist. Theology 92, 85-92.

Driver, T F 1987. The case for pluralism, in Hick, J \& Knitter, P F (eds), The myth of Christian uniqueness:Toward a pluralistic theology of religions, 203-218. Maryknoll, NY: Orbis Books.

Hick, J 1990. Review of "Towards a theology of religions". Religious Studies 26(1), 175177.

Knitter, P F 1985. No other name? A critical survey of Christian attitudes toward the world religions. London: SCM.

Knitter, P F 1986. Catholic theology of religions at a crossroads, in Küng, H \& Moltmann, J (eds), Christianity among world religions, 99-107. Edinburgh: T \& T Clark.

Knitter, P F 1987. Toward a liberation theology of religions, in Hick, J \& Knitter, P F (eds), The myth of Christian uniqueness: Toward a pluralistic theology of religions, 178-200. Maryknoll, NY: Orbis Books.

Küng, H 1966. Freedom today. New York: Sheed Ward.

Küng, H 1969. The freedom of religions, in Thomas O C (ed), Attitudes toward other religions: Some Christian interpretations, 193-217. London: SCM.

Küng, H 1974. Christ sein. München: R Piper.

Küng, H 1976. On being a Christian, tr by E Quinn. New York: Doubleday.

Küng, H 1978. Existiert Gott?: Antwort auf die Gottesfrage der Neuzeit. München: R Piper.

Küng, H 1985. Christentum und Weltreligionen. München: R Piper.

Küng, H 1986a. Introduction: The debate on the word "religion". Concilium 183, xi-xv.

Küng, H 1986b. Towards an ecumenical theology of religions: Some theses for clarification. Concilium 183, 119-125.

Küng, H 1986c. Christianity and the world religions, tr by $\mathrm{P}$ Heinegg. New York: Doubleday.

Küng, H 1987. Why I am still a Christian, tr by E C Hughes. Edinburgh: T \& T Clark. 
Küng, $\mathrm{H}$ 1988a. What is true religion? Toward an ecumenical criteriology, in Swidler, L (ed), Toward a universal theology of religion, 231-250. Maryknoll, NY: Orbis Books.

Küng, $\mathrm{H}$ 1988b. Theology for the third millenium: An ecumenical view, tr by $\mathrm{P}$ Heinegg. New York: Doubleday.

Küng, H 1989a. Paradigm change in theology: A proposal for discussion, in Küng, H \& Tracy, D (eds), Paradigm change in theology, tr by M Köhl. Edinburgh: T \& T Clark.

Küng, H 1989b. A new basic model for theology: Divergencies and convergencies, in Küng, H \& Tracy, D (eds), Paradigm change in theology, tr by M Köhl. Edinburgh: T \& T Clark.

Küng, H 1990a. Geen wereldvrede zonder godsdienstvrede: Een oecumenische weg tussen waarheidsfanatisme en waarheidsvergetelheid, in Küng, $\mathrm{H}$ et al (eds), Godsdienst op een keerpunt, 22-60. Kampen: Kok Agora.

Küng, H 1990b. Godsdienst op een keerpunt: Een theologische tijdanalyse, in Küng, H et al (eds), Godsdienst op een keerpunt, 61-84. Kampen: Kok Agora.

Küng, H 1990c. Reforming the church today, tr by $P$ Heinegg. New York: Crossroad. Küng, H 1991a. Global responsibility, tr by J Bowden. London: SCM.

Küng, H 1991b. Dialogability and steadfastness: On two complementary virtues, in Jeanrond, W G \& Rike, J L (eds), Radical pluralism and truth: David Tracy and the hermeneutics of religion, 237-249. New York: Crossroad.

Küng, H 1992. Against contemporary Roman Catholic fundamentalism, tr by J Bowden in Küng, $\mathrm{H}$ \& Moltmann, J (eds), Fundamentalism as an ecumenical challenge, 116-125. London: SCM.

Küng, H 1994a. World peace - world religions - world ethic, in Küng, H \& Moltmann, J (eds), Islam: A challenge for Christianity, 127-139. London: SCM.

Küng, H 1994b. Great Christian thinkers, tr by J Bowden. Londen: SCM.

Küng, H 1995. Clash of civilizations or world peace through religious peace, in Ulrich, P \& Sarasin, C (eds), Facing public interest: The ethical challenge to business policy and corporate communications, 11-27. Dordrecht: Kluwer.

Küng, H 1996. Christianity: Essence, history, and future, tr by J Bowden. New York: Continuum.

Küng, $\mathrm{H}$ 1998. Don't be afraid of ethics! Why we need to talk of responsibilities as well as rights, in Küng, $\mathrm{H}$ \& Schmidt, $\mathrm{H}$ (eds), A global ethic and global responsibilities: Two declarations, 104-122. London: SCM.

Lambert, B C 1990. Reflections on Hans Küng's theology for the third millenium. Modern Age 33, 157-164.

Louw, D J 1997. Die neo-eksklusivistiese benadering tot religieuse pluraliteit. The South African Journal of Philosophy 16(3), 94-100.

Louw, D J 2000a. Oor die moontlikheid van interreligieuse kommunikasie. South African Journal of Philosophy 19(3), 255-278.

Louw, D J 2000b: "On evaluating religions: Beyond objectivism and relativism". Theologia Viatorum: Journal of Theology and Religion in Africa 26, 45-73.

Louw, D J 2004a. Die neo-inklusivistiese benadering tot religieuse pluraliteit. South African Journal of Philosophy 23(1), 1-27.

Louw, D J 2004b. Op soek na ekumeniese kriteria: Meta-religieuse kriteria. South African Journal of Philosophy 23(3), 302-326. 


\section{Hans Küng en religieuse pluraliteit}

Rahner, K 1978. Foundations of Christian faith: An introduction to the idea of Christianity, tr by W V Dych. London: Darton, Longman \& Todd.

Rahner, K 1981. Christianity and the non-Christian religions, in Hick, J \& Hebblethwaite, B (eds), Christianity and other religions, 52-79. Philadelphia, PA: Fortress Press.

Rhem, R A 1986. Theological method: The search for a new paradigm in a pluralistic age. Reformed Review 39(3), 242-254.

Thomas, O C (ed) 1969. Attitudes toward other religions: Some Christian interpretations. London: SCM. 